\title{
Trial Elements Supplemental Qualifiers Dataset
}

National Cancer Institute

\section{Source}

National Cancer Institute. Trial Elements Supplemental Qualifiers Dataset. NCI

Thesaurus. Code C147256.

A dataset containing supplemental information, specifically non-standard variables, to parent records in the trial elements domain. 